\title{
The Evaluation of High-Degree Geopotential Models for Regional Geoid Determination in Turkey
}

\author{
Mustafa Yılmaz ${ }^{1,{ }^{*}}$, Bayram Turgut ${ }^{1}$, Mevlüt Güllü ${ }^{1}$, Ibrahim Yılmaz ${ }^{1}$ \\ ${ }^{1}$ Afyon Kocatepe Üniversitesi, Mühendislik Fakültesi, Harita Mühendisliği Bölümü, Afyonkarahisar, Türkiye \\ *Corresponding author, E-mail: mustafayilmaz@aku.edu.tr
}

\begin{tabular}{|c|c|}
\hline & \\
\hline $\begin{array}{c}\text { Keywords } \\
\text { Geoid; } \\
\text { Geopotential model; } \\
\text { GNSS/levelling. }\end{array}$ & $\begin{array}{l}\text { High-degree geopotential models of spherical harmonic coefficients are used for modelling the exterior } \\
\text { gravity field of the Earth. These coefficients are derived from satellite tracking data, altimeter data, and } \\
\text { terrestrial and airborne gravity data. Hundreds of thousands of coefficients and standard deviation } \\
\text { values for these coefficients are estimated from millions of measurements. The geopotential model } \\
\text { accuracy is affected by the amount, the distribution and the type of measurements. The satellite gravity } \\
\text { field missions have provided accurate data forming geopotential models since } 1960 \text { 's. The geopotential } \\
\text { models related to the satellite gravity field missions are experienced by interior validation (estimated } \\
\text { error degree variances of fully-normalized coefficients) or outer validation (comparison of model based } \\
\text { gravity anomalies and geoid heights with terrestrial measurements). In this paper, recent high-degree } \\
\text { geopotential models are primarily explained and evaluated by GNSS/levelling data of a selected study } \\
\text { area. The objective of this evaluation is to determine the high-degree geopotential model giving a } \\
\text { better fit to the GNSS/levelling data over the study area for the contribution to the regional geoid } \\
\text { determination studies in Turkey. }\end{array}$ \\
\hline
\end{tabular}

\section{Türkiye'de Bölgesel Jeoid Tespiti için Yüksek Dereceli Jeopotansiyel Modellerin Değerlendirilmesi}

\begin{abstract}
Özet
Küresel harmonik katsayılardan oluşan yüksek dereceli jeopotansiyel modeller Dünya'nın dış gravite alanının modellenmesi için kullanılır. Bu katsayılar uydu takip verisinden, altimetre verisinden ve yersel graviteden türetilir. Yüzbinlerce katsayı ve bu katsayıların standart sapma değerleri milyonlarca ölçümden hesaplanır. Jeopotansiyel modelin doğruluğu ölçümlerin miktarından, dağılımından ve türünden etkilenir. Uydu gravite görevleri, 1960 lardan beri jeopotansiyel modelleri oluşturan doğru veri sağlamaktadır. Uydu gravite görevleri ile bağlantılı jeopotansiyel modeller iç geçerlilik (tam normalleştirilmiş katsayıların hesaplanan hata derece varyansları) veya dış geçerlilik (model bazlı gravite anomalilerinin ve jeoid yüksekliklerinin yersel ölçüler ile karşılaştırılması) ile değerlendirilir. Bu çalışmada, güncel yüksek dereceli jeopotansiyel modeller öncelikli olarak açıklanmış ve seçilmiş bir çalışma alanında GNSS/nivelman verisi kullanılarak değelendirilmiştir. Bu değerlendirmenin amacı, Türkiye'deki bölgesel jeoid tespiti çalışmalarına katkıda bulunmak için, çalışma alanındaki GNSS/nivelman verisine daha iyi uyan yüksek dereceli jeopotansiyel modelin belirlenmesidir.
\end{abstract}

(c) Afyon Kocatepe Üniversitesi

\section{Introduction}

The geoid surface serves as a reference for most applications that require a datum for determining topographic heights or ocean depths. The improvements derived from recent satellite gravity missions have significantly improved accurate knowledge of the Earth's gravity field, such that global geopotential models (GGMs) representing the gravity field of the Earth have got high importance for all geosciences.

The technological and scientific developments in satellite techniques and computation algorithms provide significant improvements in the determination of the global gravity field models. 
Since the launch of the CHAllenging Minisatellite Payload (CHAMP), Gravity Recovery And Climate Experiment (GRACE), and Gravity field and steadystate Ocean Circulation Explorer (GOCE) missions (2000, 2002, and 2009 respectively), numerous GGMs have become available to the scientific community through the public domain (http://icgem.gfz-potsdam.de/ICGEM). Especially, the Earth Gravitational Model 2008 (EGM2008) released by the National Geospatial-Intelligence Agency EGM Development Team (Pavlis et al., 2008) and the European Improved Gravity model of the Earth by New techniques (EIGEN-5C) released by the GFZ Postdam-GRGS Toulouse collaboration (Förste et al., 2008) are notable attainments in the gravitational field resolution of the Earth. These high-degree models lead to significant improvement of our knowledge of the long wavelength part of the Earth's static gravitational field, and thereby of the long wavelengths of the geoid. Therefore, corresponding improvements are expected for precise regional geoid model determination because regional geoid models typically include a GGM as underlying geopotential representation (Erol et al., 2009).

The geodesy community engaged in comprehensive efforts for the comparison and validation of GGMs using various techniques and independent data sources that were not utilized for the design and validation of GGMs. To improve local geoid models, it is essential to select the best GGM for the studied area. Frequently, error estimates are not used to decide which GGM is appropriate in geoid determination for a certain region. Due to their optimism, the quality estimates are not used as performance indicators of GGMs in a particular area. Therefore, private reliability-precision validations should be executed by the users of GGMs (Kiamehr and Sjöberg, 2005). The sustained advancements in the acquiring, understanding, and modelling of GNSS data have ensured geodesists with accurate and precise exterior control for evaluating global-regional gravity field models of the Earth (Kotsakis, 2008). The major objective of this paper is to compare high-degree GGMs: EGM2008, EIGEN-6C4, and
GOCE-EGM2008 COmbined model (GECO). Geoid heights determined from Global Navigation Satellite System (GNSS)/Levelling over the Internal Aegean Region study area were used to verify the accuracy of GGMs for specifying the high-degree geopotential model that has the best fit to GNSS/Levelling data over the study area for further regional geoid determination studies.

\section{Theoretical Background}

\subsection{GNSS/Levelling}

GNSS-derived ellipsoidal heights refer to a reference ellipsoid, while orthometric heights refer to an equipotential reference surface determined through levelling. When these heights are collocated at the same benchmark, geoid heights can be determined by their difference through a geometrical approach. GNSS/Levelling geoid heights are computed by (Heiskanen and Moritz, 1967):

$N=h-H$

where $N$ represents the geoid height, $h$ is the ellipsoidal height calculated from GNSS measurements and $H$ is the orthometric height obtained by levelling (Fig. 1). The (known) ellipsoidal and orthometric heights are utilized to compute the geoid heights (Banarjee et al., 1999). Eq. (1) is not exact due to the ignorance of the deflection of the vertical $(\varepsilon)$. Nevertheless, it is accurate enough for most practical applications, because $\varepsilon$ has a negligible influence (sub $\mathrm{mm}$ order) on the orthometric height (Tenzer et al., 2005).

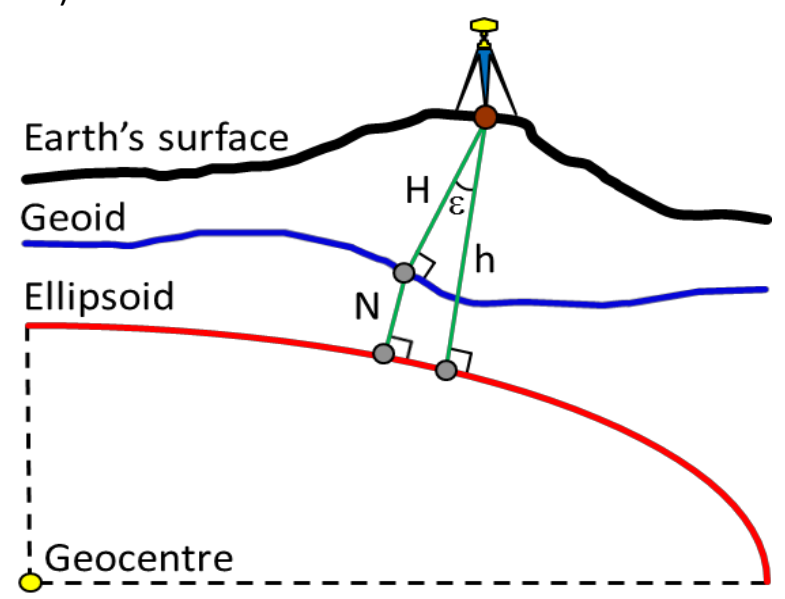

Figure 1. The relationship between the height systems 


\subsection{Global Geopotential Model}

In different fields of science and engineering, an improved knowledge of the gravitational field of the Earth (in terms of accuracy and resolution), is required for a better determination of height systems (Rummel et al., 2002). The longwavelength part of the Earth's gravity field is determined by GGMs that consist of fullynormalized, spherical harmonic coefficients (Mainville et al., 1992). The spherical harmonic coefficients are obtained from geopotential solutions by the combination of satellite tracking data, terrestrial-airborne gravity data, and satellite altimetry (Rapp, 1997).

The geoid height $(N)$ can be calculated through spherical harmonic coefficients by (Heiskanen and Moritz, 1967):

$$
N(\theta, \lambda) \approx R \sum_{l=2}^{l_{\max }} \sum_{m=0}^{l} \bar{P}_{l m}(\sin \theta)\left[\bar{C}_{l m} \cos m \lambda+\bar{S}_{l m} \sin m \lambda\right]
$$

where $(\theta, \lambda)$ co-latitude and longitude of the computation point, $R$ is the mean radius of the Earth, $\bar{P}_{\ell m}$ is the associated Legendre polynomials, $\bar{C}_{\ell m}$ and $\bar{S}_{\ell m}$ are the spherical harmonic coefficients for degree / and order $m$, respectively.

\section{Study Area, Source Data, and GGMs}

\subsection{Study Area and Height Data}

The internal Aegean region of Turkey is selected as the study area. The study area is limited by: $37^{\circ} .3083 \mathrm{~N} \leq \varphi \leq 40^{\circ} .4417 \mathrm{~N} ; 28^{\circ} .4833 \mathrm{E} \leq \lambda \leq$ $32^{\circ} .7167 \mathrm{E}$ defines a total area of $\sim 133000 \mathrm{~km}^{2}$ (350 km x $380 \mathrm{~km}$ ) with a mountainous terrain (Fig. 2).

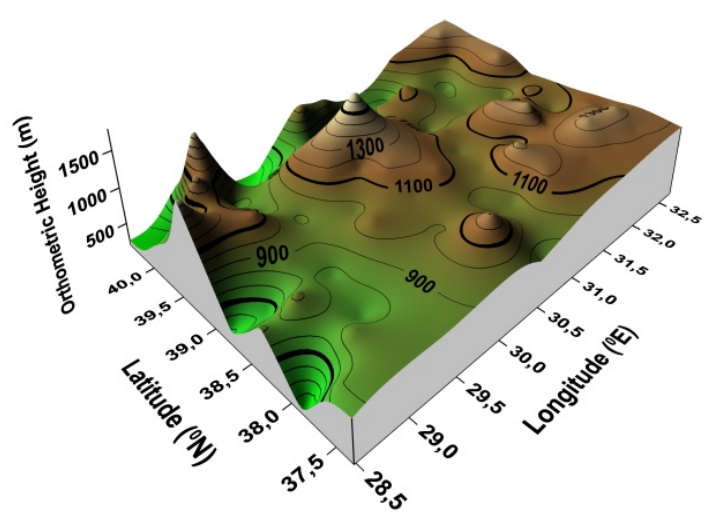

Figure 2. The topographical terrain of the study area
The evaluation procedure of GGMs (based on geoid height) refers to a source dataset that comprises 87 points belonging to Turkish National Fundamental GPS Network (TNFGN) (Fig. 3).

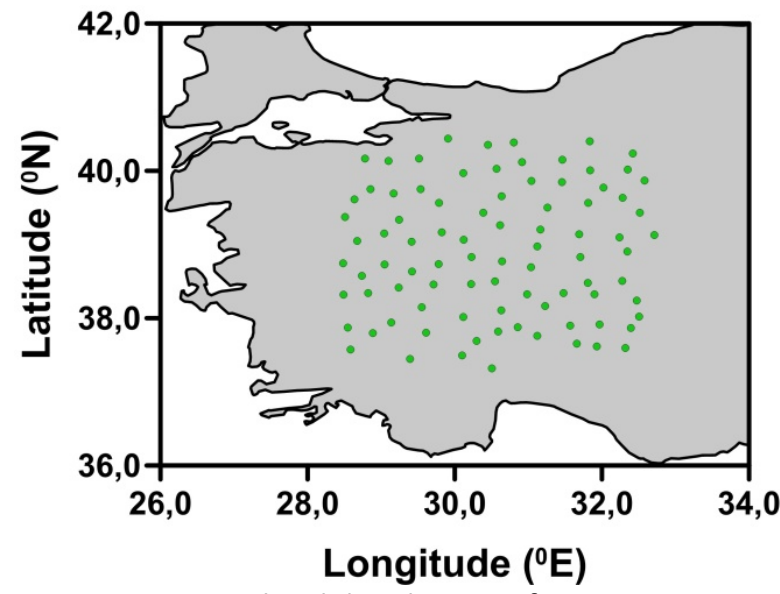

Figure 3. Geographical distribution of 87 TNFGN points

Ellipsoidal heights at 87 points have been determined using dual-frequency GNSS receivers and antennas with respect to TNFGN (ITRF962005.00 reference epoch). The orthometric heights at these points have been obtained through geometric levelling with respect to the Turkish National Vertical Control Network (mean sea level of the Antalya tide gauge). The geoid heights at 87 TNFGN points have been calculated by the known ellipsoidal and orthometric heights (Eq. (1)).

\subsection{GGMs and Evaluation Methodology}

\subsubsection{Earth Gravitational Model 2008}

EGM2008 is a spherical harmonic model of the Earth's external gravity field to degree and order 2159, with (additional) spherical harmonic coefficients extending up to degree 2190 and order 2159. EGM2008 is primarily developed in ellipsoidal harmonics to degree and order 2160 and transformed to spherical harmonics. It is a least squares combination of:

- ITG-GRACEO3S gravitational model and its associated error covariance matrix.

- The gravitational defined on a 5 arc-minute equiangular grid that was formed by merging terrestrial, altimetry-derived, and airborne gravity data.

The spectral content of EGM2008 was provided by gravitational information indicated with the 
topography over areas where only lower resolution gravity data were available. (Pavlis et al., 2012). The national geoid model for Turkish territory, Turkish Hybrid Geoid 2009 (THG-09) (Kilicoglu et al., 2011) was computed depending on EGM2008.

\subsubsection{The Latest Combined Global Gravity Field} Model Including GOCE Data up to Degree and Order 2190

The combined gravity field model EIGEN-6C4 is the latest combined global gravity field model up to degree and order 2190. It has been elaborated jointly by GFZ Potsdam and GRGS Toulouse and including:

- LAGEOS (degree 2 - 30): 1985 - 2010

- GRACE RL03 GRGS (degree 2 - 130): ten years $2003-2012$

- GOCE-SGG data: November 2009 till October 2013

- DTU12 ocean geoid data and an EGM2008 geoid height grid for the continents (max degree 370).

The different satellite and surface data sets has been combined by a band-limited normal equations (to max degree 370) generated from observation equations for the spherical harmonic coefficients. The resulting model to degree and order 370 has been extended to degree and order 2190 by a block diagonal solution using the DTU10 global gravity anomaly data grid (Förste et al., 2015).

\subsubsection{The Global Gravity Model by Locally Combining GOCE Data and EGM2008}

GECO is a global gravity model, computed by incorporating the GOCE-only TIM R5 solution into EGM2008. The input data of GECO:

- EGM2008 spherical harmonic coefficients and corresponding error standard deviations

- EGM2008 global grid of geoid error standard deviations (5' $\times$ 5' resolution)

- GOCE TIM R5 spherical harmonic coefficients

- GOCE TIM R5 block-diagonal coefficient error covariance matrix.

EGM2008 geoid undulations are computed on a global spherical grid of resolution $0.5^{\circ} \times 0.5^{\circ}$ by making a synthesis from EGM2008 coefficients up to degree 359. The GOCE geoid on the same grid are computed by making a synthesis from the TIM R5 coefficients up to degree 250. Two geoid grids are merged by least-squares adjustment. Finally, the GECO spherical harmonic coefficients are computed by making an analysis of the combined global geoid grid. The analysis is performed up to degree 359 (consistently with the $0.5^{\circ} \times 0.5^{\circ}$ resolution). From degree 360 to degree 2190 the GECO coefficients are the same of EGM2008. The GECO coefficient errors are computed as a weighted average of the coefficient errors of EGM2008 and the TIM R5 solution (Gilardoni et al., 2016).

\subsubsection{GGM Evaluation}

The utilized GGMs for geoid height calculation over the study area are given in Table 1 with respect to model characteristics.

Table 1. GGMs used for the evaluation (S: Satellite tracking, G: Gravity, A: Altimetry).

\begin{tabular}{lccc}
\hline \multicolumn{1}{c}{ Model } & Year & Degree & Data \\
\hline EGM2008 & 2008 & 2190 & S (GRACE), G, A \\
EIGEN-6C4 & 2014 & 2190 & S (GOCE, GRACE, LAGEOS), G, A \\
GECO & 2015 & 2190 & S (Goce), EGM2008 \\
\hline
\end{tabular}

The geoid heights based on GNSS-derived ellipsoidal heights and geometric levelled orthometric heights at distinct points provide an estimated accuracy of the GGM's for the GGM evaluation procedure. The usual and accepted practice is to select the GGM that has a best fit to the geoid height determined from the GNSS/levelling. The evaluation of GGMs focuses on the correspondent geoid height differences between the GGMs and GNSS/levelling using the equation below:

$\Delta N=N_{G N S S / L e v}-N_{G G M}$

where $\Delta N$ is the geoid height residual, $N_{\text {GNSS/Lev }}$ is the geoid height estimated from GNSS/levelling, and $N_{G G M}$ is the geoid height estimated from GGMs. For the statistical analysis of geoid height differences, minimum and maximum values of $\Delta N$ are determined and the overall performance of GGMs is assessed through RMSE accuracy measure defined by: 


$$
R M S E=\sqrt{\frac{1}{n} \sum_{k=1}^{n}(\Delta N)^{2}}
$$

where $n$ is the number of the points used for the accuracy verification and $k$ refers to the residual sequence.

\section{Comparative Study}

For the evaluation process, the geoid heights based on GGMs are interpolated from (the closest) grid points by calculation software obtained from International Centre for Global Earth Models (ICGEM) web page http://icgem.gfzpotsdam.de/ICGEM. The calculation procedure use the Kriging interpolation method and refer to the reference system World Geodetic System - 1984. Due to the affects of datum inconsistencies on the differences between GNSS/levelling based geoid heights and GGM-based geoid heights, a transformation (4-parameter) (Kotsakis et al., 2009 ) is used to minimize the offsets (i.e. bias and tilt). After fitting the tilt, the geoid heights based on GGMs are compared with individual geoid heights obtained from GNSS/levelling data. The statistical values of the height data sets that were used for GGM evaluation process are listed in Table 2.

Table 2. Statistics of height datasets over the study area (units in $\mathrm{m}$.)

\begin{tabular}{lcccc}
\hline \multicolumn{1}{c}{ Height } & Min. & Max. & Mean & Std. Dev. \\
\hline $\mathrm{h}$ & 203.789 & 1865.758 & 1040.760 & 308.983 \\
$\mathrm{H}$ & 168.566 & 1827.319 & 1003.724 & 308.899 \\
$\mathrm{~N}_{\text {GNSS/Lev }}$ & 32.120 & 38.927 & 37.036 & 1.321 \\
$\mathrm{~N}_{\text {EGM2008 }}$ & 27.835 & 40.179 & 36.280 & 2.171 \\
$\mathrm{~N}_{\text {EIGEN-6C4 }}$ & 27.869 & 40.208 & 36.285 & 2.162 \\
$\mathrm{~N}_{\text {GECO }}$ & 27.935 & 40.184 & 36.288 & 2.160 \\
\hline
\end{tabular}

The graphical representations have been adopted for the comparative evaluation of GGMs by producing a residual map for each GGM (Fig. 4-6) that indicates the occurrence and magnitude of geoid height differences. The residual maps are produced by the Surfer ${ }^{\circledR} 13$ software before fitting the tilt.

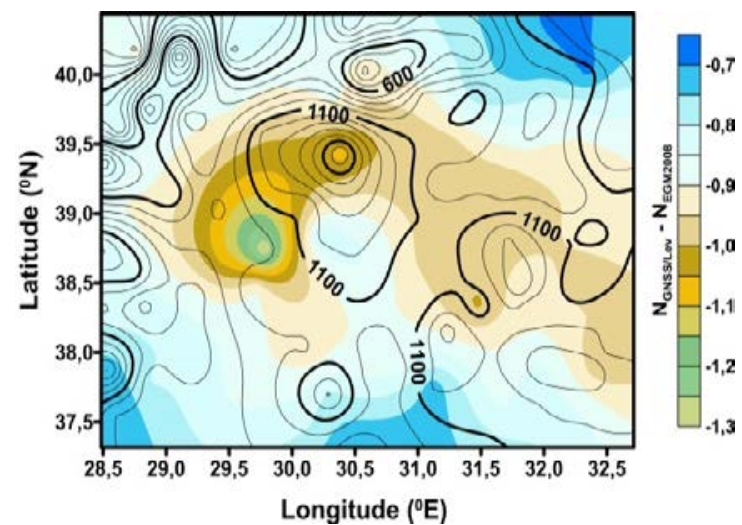

Figure 4. EGM2008 residual map (differences in $\mathrm{m}$.)

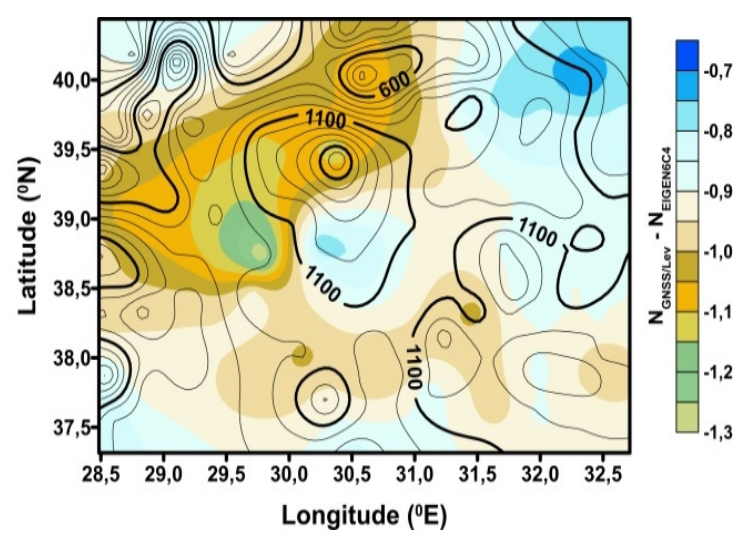

Figure 5. EIGEN-6C4 residual map (differences in $\mathrm{m}$.)

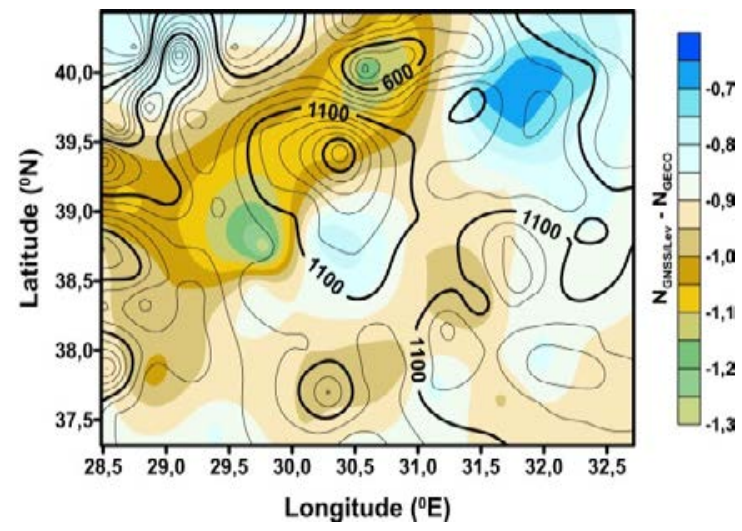

Figure 6. GECO residual map (differences in $\mathrm{m}$.)

\section{Results and Conclusions}

The visual analysis of the geoid height residual maps shows that the deviation of EGM2008 based geoid heights from GNSS/levelling based geoid heights is reduced for most parts of the study area ( - $0.8 \mathrm{~m}$. before fitting the tilt). It is visible from Fig.4 that EGM2008 approximates the terrain better than the other GGMs.

When the global statistics of geoid height residuals based on high-degree GGMs summarized in Table 3 are evaluated, the following conclusions can be drawn: 
(i) The higher frequency content of EGM2008, EIGEN-6C4, and GECO have affected the results. (ii) EGM2008 provides more accurate results than EIGEN6C4 and GECO.

Table 3. Statistics of $\left(\mathrm{N}_{\mathrm{GNSS} / \mathrm{Lev}}-\mathrm{N}_{\mathrm{GGM}}\right)$ over the study area after fitting the tilt (units in $\mathrm{m}$.)

\begin{tabular}{lcccc}
\hline \multicolumn{1}{c}{ Model } & Min. & Max. & Mean & RMSE \\
\hline EGM2008 & -0.774 & -0.170 & -0.305 & 0.280 \\
EIGEN-6C4 & -0.784 & -0.176 & -0.323 & 0.328 \\
GECO & -0.796 & -0.156 & -0.325 & 0.332 \\
\hline
\end{tabular}

The RMSE values of $\left(N_{\text {GNSS/Lev }}-N_{G G M}\right)$ were selected to make inference about the best fit of the highdegree GGMs to the GNSS/levelling data for model evaluating because any gravimetric geoid determination is inadequate in the zero and firstdegree terms. Obviously, EGM2008 fit the GPS/levelling data better than EIGEN6C4 and GECO over the study area.

The results of high-degree GGM evaluation in this study have pointed out the authority of EGM2008 to EIGEN-6C4 and GECO. EGM2008 fits best to the THG-09 at $\pm 0.280 \mathrm{~m}$. agreement despite the coefficient errors and GNSS/levelling dataset that can not be contemplated as completely accurate. Based on the GGM evaluation results of this paper, it can be concluded that EGM2008 can be used as a reference high-degree geopotential model for further geoid determinations at regional scales.

Due to improvements in instrumentation, software, processes, and applications, high-degree GGMs (e.g. up to degree and order 2190) are major steps to represent the gravity field of the Earth with a high accuracy. Nowadays high-degree gravity field models, mainly derived from satellite measurements, become more and more detailed and accurate. These gravity field models should be combined with terrestrial gravity anomalies) and GNSS/levelling-derived or altimetry-derived geoid heights. Furthermore, an important task of geodesy is to make the gravity field functionals available to other geosciences. For all these purposes, it is necessary to calculate the corresponding functionals as accurately as possible or, at least, with a well-defined accuracy from a given global gravity field model. Therefore, in order to achieve significant developments for the highresolution gravimetric geoid models in Turkey, further and future analysis of high-degree GGMs (e.g. GOCE-based GGMs) will be needed.

\section{Acknowledgements}

This study was supported by Afyon Kocatepe University Scientific Research Projects Coordination Department (Project No: 15.HIZ.DES.91) and presented in ISCAS-2016.

\section{References}

Banarjee, P., Foulger, G.R., Satyaprakash, Dabral, C.P. (1999). Geoid undulation modelling and interpretation at Ladak, NW Himalaya using GPS and levelling data. Journal of Geodesy, 73, 79-86.

Erol, B., Sideris, M.G., Celik, R.N. (2009). Comparison of global geopotential models from the champ and grace missions for regional geoid modelling in Turkey. Studia Geophysica et Geodaetica, 53, 419-441.

Förste, C., Flechtner, F., Schmidt, R., Stubenvoll, R., Rothacher, M., Kusche, J., Neumayer, K.H., Biancale, R., Lemoine, J.-M., Barthelmes, F., Bruinsma, S., König, R., Meyer, U. (2008). EIGEN-GL05C - A new global combined high-resolution GRACE-based gravity field model of the GFZ-GRGS cooperation. Geophysical Research Abstracts, Vol. 10, EGU2008-A-03426, SRef-ID: 16077962/gra/EGU2008-A-03426, 2008.

Förste, C., Bruinsma, S.L., Abrikosov, O., Lemoine, J.-M., Marty, J.C., Flechtner, F., Balmino, G., Barthelmes, F., Biancale, R. (2015). EIGEN-6C4 The latest combined global gravity field model including GOCE data up to degree and order 2190 of GFZ Potsdam and GRGS Toulouse. http://dx.doi.org/10.5880/icgem.2015.1.

Gilardoni, M., Reguzzoni, M., Sampietro, D. (2016). GECO: a global gravity model by locally combining GOCE data and EGM2008. Studia Geophysica et Geodaetica, 60, 228-247.

Heiskanen, W.A., Moritz, H. (1967). Physical Geodesy.W.H. Freeman, San Francisco.

Kiamehr, R., Sjöberg, L.E. (2005). Comparison of the qualities of recent global and local gravimetric geoid models in Iran. Studia Geophysica et Geodaetica, 49, 289-304. 
Kilicoglu, A., Direnc, A., Yildiz, H., Bolme, M., Aktug, B., Simav, M., Lenk, O. (2011). Regional gravimetric quasigeoid model and transformation surface to national height system for Turkey (THG-09). Studia Geophysica et Geodaetica, 55, 557-578.

Kotsakis, C. (2008). Transforming ellipsoidal heights and geoid undulations between different geodetic reference frames. Journal of Geodesy, 82, 249-260.

Kotsakis, C., Katsambalos, K., Gianniou, M. (2009). Evaluation of EGM08 based on GPS and orthometric heights over the Hellenic mainland. Newton's Bulletin, 4, 144-163.

Mainville, A., Forsberg, R., Sideris, M.G. (1992). Global positioning system testing of geoids computed from geopotential model and local gravity data: a case study. Journal of Geophysical Research, 97 (B7), 11137-11147.

Pavlis, N.K., Holmes, S.A., Kenyon S.C., Factor J.K. (2008). An earth gravitational model to degree 2160: EGM2008. General Assembly of the European Geosciences Union, 13-18 April, Vienna, Austria.

Pavlis, N.K., Holmes, S.A., Kenyon, S.C., Factor, J.K. (2012). The development and evaluation of the Earth Gravitational Model 2008 (EGM2008). Journal of Geophysical Research, 117, B04406, doi: 10.1029/2011JB008916.

Rapp, R.H. (1997). Past and future developments in geopotential modelling, in: Forsberg, R, Feissl, M., Dietrich, R. (Eds.) Geodesy on the Move, Springer, Berlin, pp. 58-78.

Rummel, R., Balmino, G., Johannessen, ., Visser, P., Woodworth, P. (2002). Dedicated gravity field missionsprinciples and aims. Journal of Geodynamics, 33, 3-20.

Tenzer, R., Vanicek, P., Santos, M., Featherstone, W.E., Kuhn, M. (2005). The rigorous determination of orthometric heights. Journal of Geodesy, 79, 82-92. 